\title{
Correction to: Carbon sequestration and nitrogen uptake in a temperate silvopasture system
}

\author{
C. Dold (1) • Andrew L. Thomas • A. J. Ashworth • D. Philipp • D. K. Brauer • \\ T. J. Sauer
}

Published online: 12 October 2020

(C) This is a U.S. government work and its text is not subject to copyright protection in the United States; however, its text may be subject to foreign copyright protection 2020

\section{Correction to:}

Nutr Cycl Agroecosyst (2019) 114:85-98

https://doi.org/10.1007/s10705-019-09987-y

In the original publication of the article, the Abstract was published with an error in a sentence. The correct version is given with this Correction.

In Abstract, the sentence beginning " $\mathrm{DW}_{\mathrm{w}}$ and $\mathrm{C}_{\mathrm{w}}$ was 7.1 and 3.4 $\mathrm{Mg} \mathrm{ha}^{-1}$ for pecan...", should read as

The original article can be found online at https://

doi.org/10.1007/s10705-019-09987-y.

C. Dold $(\bowtie) \cdot$ T. J. Sauer

National Laboratory for Agriculture and the Environment, USDA-ARS, Ames, IA 50011-3120, USA

e-mail: Christian.Dold@ars.usda.gov

T. J. Sauer

e-mail: Tom.Sauer@ars.usda.gov

\section{A. L. Thomas}

Division of Plant Sciences, Southwest Research Center, University of Missouri, 14548 Highway H Mt, Vernon, MO 65712, USA

e-mail: ThomasAL@missouri.edu

\footnotetext{
A. J. Ashworth

Poultry Production and Products Safety, Research Unit,

Science Center, USDA-ARS, University of Arkansas,

Fayetteville, AR, USA

e-mail: Amanda.Ashworth@ars.usda.gov
}

" $\mathrm{DW}_{\mathrm{w}}$ and $\mathrm{C}_{\mathrm{w}}$ was 7.1 and $3.4 \mathrm{Mg} \mathrm{ha}^{-1}$ for pecan and 26.6 and $12.7 \mathrm{Mg} \mathrm{ha}^{-1}$ for oak, which corresponds to a carbon sequestration rate of 0.20 (Pecan) and 0.75 (Oak) $\mathrm{Mg} \mathrm{C} \mathrm{ha} \mathrm{yr}^{-1}$, respectively."

Publisher's Note Springer Nature remains neutral with regard to jurisdictional claims in published maps and institutional affiliations.
D. Philipp

Division of Agriculture, Department of Animal Science, AFLS B114, University of Arkansas, Fayetteville, AR 72701, USA

e-mail: dphilipp@uark.edu

D. K. Brauer

USDA-ARS Conservation and Production Research Lab, 300 Simmons RD, Unit 10 (2300 Experiment Station RdShip), Bushland, TX 79012, USA

e-mail: david.brauer@ars.usda.gov 